Conclusion This multi-layered risk evaluation should aid the future management of children attending the PED being investigated for SBI.

\section{PROCALCITONIN IN PEDIATRIC EMERGENCY DEPARTMENTS FOR THE DIAGNOSIS OF INVASIVE INFECTIONS}

doi:10.1136/archdischild-2012-302724.1579

${ }^{1} \mathrm{C}$ Zavarache, 1,20 Falup-Pecurariu. 'Department of Pediatrics, University Children's Hospital; '2Department of Pediatrics, Faculty of Medicine, Transilvania University, Brasov, Romania

Background Procalcitonin is used in pediatric emergency departments for the early diagnosis of invasive bacterial infections, especially for febrile children.

Aim of the Study To evaluate the usefulness of a rapid semiquantitative test of procalcitonin for the diagnoses of invasive diseases at children.

Methods We have prospectively evaluated 25 patients divided into two groups: 1) group A with 6 patients having viral infections and 2) group $B$ with bacterial infections comprised of 19 patients. For this group we had a score made of leucocytes over $16000 / \mathrm{mm}^{3}$, granulocytes over $12000 / \mathrm{mm}^{3}$, erythrocyte sedimentation rate $(\mathrm{ESR})>50 \mathrm{~mm} / \mathrm{h}$ and $\mathrm{C}$ reactive protein $(\mathrm{CRP})>2.4 \mathrm{mg} / \mathrm{dl}$, procalcitonin (CPT) $>0.5 \mathrm{ng} / \mathrm{ml}$.

Results The analysis of ROC curves shows the degree in which inflammatory tests may distinguish between the two groups. This suggests that the quality of separation between the two groups was 0.86 for CPT, 0.85 for CRP, 0.67 for leucocytes, 0.62 for granulocytes and 0.82 for ESR $(p<0.001)$.

Conclusion Procalcitonin has a higher specificity and sensitivity compared to the other acute phase reactants (leucocyte number, neutrophil number, ESR and CRP respectively). Procalcitonin may be considered in the emergency department as a valuable diagnostic tool in order to distinguish between viral and bacterial infections at children.

\section{LUMBAR PUNCTURE(LP) IN INFANTS AND CHILDREN WITH SUSPECTED MENINGITIS-DIAGNOSTIC YIELD OVER 15 YEARS}

doi:10.1136/archdischild-2012-302724.1580

Z Barsoum. Paediatrics, Mercy University Hospital, Cork, Ireland

Background Bacterial meningitis is a serious disease that leads to much anxiety among the medical profession and parents.LP has long been a key tool for the diagnosis of meningitis.

Objectives To determine the diagnostic yield from LP over 15 years in Mid Western region of Ireland.

Methods A retrospective cohort analysis of laboratory data of all lumbar punctures performed from July 1996 to December 2010 in Paediatric department Mid Western Regional Hospital and maternity Hospital-Limerick-Ireland.

Results 1487 LPs were performed from July 1996 to December 2010.646 samples were obtained from July 1996 to December 2000 and 463 samples obtained from January 2001 to December 2005. 378 LPs were performed from 2006 to 2010.967 patients (65\%) were 2 years or younger.18/1487(1.2\%) patients had bacterial meningitis from 2001 to 2010, 15/18 (83\%) were infants. CSF leucocytosis was noted in $17 / 18$ patients(94\%). Nisseria meningitidis B and Strypt. Pneumoniae were isolated in $38 \% \& 27 \%$ of cases respectively. Serum PCR was positive in $77 \%$ of cases. CSF PCR was positive in $100 \%$ of cases. Both CSF and blood culture were positive in $44 \%$ of cases.

Conclusion The incidence of bacterial meningitis is decreasing due to effective vaccination(18/1487 patients (1.2\%),83\% infants. The role of LP in the diagnosis of meningitis is crucial. Nisseria meningitidis type $\mathrm{B}$ is the leading cause of bacterial meningitis over the last decade. CSF leucocytes are better indicators of disease than white blood cells.CSF PCR testing is more sensitive than serum PCR in the diagnosis of disease and should be requested in all cases with suspected meningitis.

\section{ASSOCIATION OF TACHYCARDIA WITH SERIOUS BACTERIAL INFECTION IN YOUNG CHILDREN}

doi:10.1136/archdischild-2012-302724.1581

J Abbasi, IF Thopte. Depeartment of Paediatrics, York District Hospital, York, UK

Background and Aim Diagnosis of a serious bacterial infection (SBI) in young children can be challenging. Clinical features at presentation are used to guide investigation and management. We aimed to determine whether tachycardia is associated with a higher risk of SBI.

Methods Prospective cohort study of children $<6$ years old referred to a children's acute assessment unit with documented or reported temperature (July 2011 - February 2012). We examined the association between maximum heart rate during admission (Heart rate: $\geq 90^{\text {th }}$ percentile for age corrected for temperature) and confirmed SBI (defined as per NICE guidelines).

Results 120 children participated. 37 children were tachycardic 21 children had a confirmed SBI.

Abstract 1581 Table 1 Senstivity/specificity data

\begin{tabular}{lcccl}
\hline & Disease +ve & Disease -ve & Total & \\
\hline Test positive & 14 & 23 & 37 & Sensitivity 0.66 \\
Test negative & 7 & 76 & 83 & Specificity 0.79 \\
Positive predictive value & 0.37 & & & \\
Negative predictive value & & 0.95 & & \\
\hline
\end{tabular}

Conclusions In this cohort of young children referred to an acute assessment unit with fever, the presence of tachycardia did not predict reliably SBI, but absence of tachycardia excluded SBI in $95 \%$ of children.

\section{OUR EXPERIENCE IN FUNCTIONAL ENDOSCOPIC SURGERY OF PARANASAL SINUSES IN CHILDREN}

doi:10.1136/archdischild-2012-302724.1582

M Maniuc, S Diacova, L Danilov, P Ababii. Otorhinolaryngology, Pediatric Clinic, SMPhU, Chisinau, Moldova

Background Functional endoscopic paranasal sinuses surgery actually serves as a method of election in surgical treatment of pediatric sinusitis.

The Aim of our research was to analyze some results of different types of functional endoscopic sinus surgery in children.

Subjects In study were included 420 of children ( 275 boys and 145 girls) of age between 7 and 14 years old with chronic and recurrent paranasal sinusitis.

Methods We analyzed duration of hospitalization and the percentage of complete functional recovery in 3 groups of patients: I group (84 children) received the standard method, II group (131 children) the minim invasive method, III group (250 children) - minim invasive method in a proper modification, which provides partial vertical resection of the hamulus and the limited resection of anatomical structures of the osteomeatal complex. Before surgery nasal endoscopy, computer tomography of paranazal sinuses, acoustic rhinometry, the respiratory function of nose, olfaction function, motor activity of the transitory epithelium were studied. 
Results Duration of hospitalization of the I group was $6.15 \pm 0.24$ days, the II group - 5.29 \pm 0.22 days, the III group - $4.26 \pm 0.25$ days $(\mathrm{P}<0.001)$. In children of the I group $73.7 \%$ were recovered, in children of the II group - $78.2 \%$, and in children of the III group - $85.7 \%$ of children.

Conclusions The minim invasive method of endoscopical surgery in the proper modification made possible the more rapid recovery from the inflammatory process in the patients with recurrent and chronic sinusitis.

\section{CLINICAL AND ULTRASOUND EXAMINATION AFTER UNILATERAL ORCHIOPEXY}

doi:10.1136/archdischild-2012-302724.1583

${ }^{1} \mathrm{~J}$ de Laffolie, ${ }^{2} \mathrm{~S}$ Turial, ${ }^{2} \mathrm{R}$ Freudenberger, ${ }^{2} \mathrm{~V}$ Engel, ${ }^{2} \mathrm{~F}$ Schier. ${ }^{1}$ General Pediatrics and Neonatology, University of Gießen, Giessen; 2Department of Pediatric Surgery, University of Mainz, Mainz, Germany

Aim To compare testis volume and ultrasound texture post unilateral orchiopexy with the other side.

Methods Clinical re-examination and ultrasound measurement of testicle volume and echostructure were performed in 99 children after unilateral orchiopexy, performed between 2003 and 2007.

Results Intraoperatively, 30 testis were described as hypoplastic. further 5 patients displayed pathologic funicular structures.

On Follow-up clinical exam, 45 patients displayed a small or atrophic testis on the side of surgery. In 10 patients, the testis was described as bigger on the side of surgery.

On ultrasound, 65 patients had similar pictures on the side of surgery compared to the other side. In the group $<2$ years, volume was measured as $0.2 \mathrm{ml} \pm 0.1 \mathrm{ml}$ vs $0.4 \mathrm{ml} \pm 0.2 \mathrm{ml}$ contralaterally $(n=10)$. In the age group 3 to 5 years volume was measured $0.4 \mathrm{ml} \pm 0.2 \mathrm{ml}$ vs $0.6 \mathrm{ml} \pm 0.3 \mathrm{ml}(\mathrm{n}=41)$, in the group $6-10$ years $0.4 \mathrm{ml} \pm 0.2 \mathrm{ml}$ vs $0.5 \mathrm{ml} \pm 0.3 \mathrm{ml}(\mathrm{n}=28)$ and in 11 to 17 year-olds volume was $3.1 \pm 2.7 \mathrm{ml}$ vs $3.9 \pm 3.8 \mathrm{ml}(\mathrm{n}=11)$.

Correlation of age at surgery and postsurgery volume difference between testes was $r=0.6$ (Pearson). In an univariate variance analysis a mild influence was found by age at surgery, inguinal hernia or re-operation.

Conclusion After orchiopexy a hypotrophic testis on the side of surgery was found in an unexpectedly high proportion. Ultrasound added valuable data (volume, texture) to the clinical follow-up examination, especially when compared to the contralateral side.

\section{APPLICABILITY OF SIGMOID COLON GRAFT FOR VAGINAL REPLACEMENT (COLOVAGINOPLASTY) AT YOUNG AGE}

doi:10.1136/archdischild-2012-302724.1584

HA Al Abeissy. Obstetric Gynecology, Al Azher University, Cairo, Egypt

Objective To evaluate the applicability, feasibility, complications, short and long term results of vaginoplasty by using sigmoid colon graft with the use of stapler for resuming colonic continuity in children with absent vagina.

Patients and Methods The records of 17 patients, 12 of them had Congenital Adrenal Hyperplasia (CAH), 3 had Androgen Insensitivity Syndrome (AIS) and 2 had vaginal atresia underwent sigmoid graft vaginal reconstruction with the aid of circular stapler during a period of 5 year from 2005 to 2010 were reviewed retrospectively.

Results A neovagina was constructed in 17 patients aged from 1 to 8 years (mean 3 years) during the study period, where sigmoid colon was used in all patients. Hospital stay ranged from 5 to 12 days (mean 7), operative time ranged from 60 to 120 min (mean 75). Complications occurred in 4 patients, introital stenosis in 2 patients, one of them necessitates revision of the introits and 2 cases had wound minor infection. The need for neovaginal dilation was indicated in only 8 out of 17 patients. There was no complications related to bowel anastomosis, No mortality in this group, the cosmetic results were excellent in all cases, with good patient satisfaction.

Conclusion Sigmoid colovaginoplasty appears to be applicable for remedy of vaginal atresia and at any age. It is associated with a less complication rate, the long term results is satisfactory and it seems better technique than skin flaps, especially in girls who doesn't expect sexual activity shortly after surgery.

\section{UNILATERAL VERSUS BILATERAL SURGERY FOR INGUINAL HERNIA IN PREMATURE BOYS: A MULTICENTER FRENCH STUDY ON 966 CASES}

doi:10.1136/archdischild-2012-302724.1585

${ }^{1} \mathrm{O}$ Maillet, ${ }^{1} \mathrm{~S}$ Garnier, ${ }^{2} \mathrm{G}$ Podevin, ${ }^{2} \mathrm{MD}$ Leclair, ${ }^{3} \mathrm{~A}$ Arnaud, ${ }^{3} \mathrm{~B}$ Fremond, ${ }^{4} \mathrm{C}$ Linard, ${ }^{5} \mathrm{R}$ Compagnon, ${ }^{5} \mathrm{~L}$ Fourcade, ${ }^{6} \mathrm{O}$ Jaby, ${ }^{6} \mathrm{M}$ Ponet, ${ }^{7} \mathrm{~A}$ El Ghoneimi, ${ }^{7} \mathrm{~J}$ Cohen, ${ }^{7} \mathrm{~A}$ Bonnard, ${ }^{8} \mathrm{~J}$ Breaud, ${ }^{8} \mathrm{~F}$ Bastiani, ${ }^{8} \mathrm{~J} \mathrm{Kurzenne,}{ }^{9} \mathrm{M}$ Lopez Paredes, ${ }^{9} \mathrm{~F}$ Varlet, ${ }^{10} \mathrm{E}$ Sapin, ${ }^{10} \mathrm{M}$ Lirussi Borgnon, "'S Sibai, "'C Piolat, " ${ }^{11}$ Teklali, ${ }^{12} \mathrm{~L}$ Harper, 'E Sabatier, 'MP Guibal, 'D Forgues, ${ }^{1} \mathrm{H}$ Allal, ${ }^{1} \mathrm{RB}$ Galifer, ${ }^{1} \mathrm{~N}$ Kalfa. ${ }^{1}$ Pediatric Surgery, $\mathrm{CHU}$ Montpellier, Montpellier; ${ }^{2} \mathrm{CHU}$ Nantes, Nantes; ${ }^{3} \mathrm{CHU}$ Rennes, Rennes; ${ }^{4} \mathrm{CHU}$ Brest, Brest; ${ }^{5} \mathrm{CHU}$ Limoges, Limoges; ${ }^{6} \mathrm{CHI}$ Creteil, Créteil; ${ }^{7} \mathrm{APHP}$, Paris; ${ }^{8} \mathrm{CHU}$ Nice, Nice; ${ }^{9} \mathrm{CHU}$ St Etienne, St Etienne; ${ }^{10} \mathrm{CHU}$ Dijon, Dijon; ${ }^{11} \mathrm{CHU}$ Grenoble, Grenoble; ${ }^{12}$ Centre Hospitalier Regional, Saint Denis de La Réunion, France

Background and Aim Bilateral surgery was formerly advocated in premature boys with unilateral inguinal hernia to avoid a metachronous contralateral hernia and the risks of recurrent anesthesia. But the recent progress in pediatric anesthesia and the demonstrated morbidity of herniotomy during the neonatal period on fertility now question this attitude. We aimed to compare the morbidity of preventive bilateral vs elective unilateral herniotomy in premature boys with unilateral hernia and to evaluate the incidence of contralateral metachronous hernia.

Methods Retrospective multicenter analysis of 966 premature boys presenting with unilateral inguinal hernia. 558 infants benefited from unilateral herniotomy and 408 from bilateral herniotomy with a median follow up of 20 months.

\section{Results}

1. The rate of contralateral metachronous hernia after unilateral surgery was $11 \%$ ( $10 \%$ on right vs $13 \%$ on left).

2. Morbidity on the contralateral side was higher in case of preventive bilateral surgery than in metachronous hernia ( $2 \%$ vs $0.2 \% \mathrm{p}=0.003)$, especially for testicular hypotrophy $(0.70 \%$ vs $0.18 \%, p=0.3)$ and secondary cryptorchidism $(1 \%$ vs $0 \%, \mathrm{p}=0.03$ )

3. Comparison between the type anesthesias (general anesthesia versus central block) did not show significant differences depending on the type of care (unilateral or bilateral, planned or emergency).

Conclusion Systematic bilateral herniotomy is unnecessary in almost $90 \%$ of patients and has a higher morbidity than secondary surgery for metachronous hernia. These results, along with the risk of deferential damage and hypofertility reported in later adulthood, justify treating only the symptomatic side in premature boys.

\section{MINOR HYPOSPADIAS: THE "TIP OF THE ICEBERG" OF THE PARTIAL ANDROGEN INSENSITIVITY SYNDROME}

doi:10.1136/archdischild-2012-302724.1586

${ }^{1} \mathrm{~N}$ Kalfa, ${ }^{1} \mathrm{P}$ Philibert, ${ }^{1} \mathrm{~F}$ Audran, ${ }^{2} \mathrm{~A}$ Bashamboo, ${ }^{3} \mathrm{H}$ Lehors, ${ }^{3} \mathrm{M}$ Haddad, ${ }^{3} \mathrm{JM}$ Guys, ${ }^{3} \mathrm{R}$ Reynaud, ${ }^{3} \mathrm{P}$ Alessandrini, ${ }^{4} \mathrm{~K}$ Wagner, ${ }^{4} \mathrm{JY}$ Kurzenne, ${ }^{4} \mathrm{~F}$ Bastiani, ${ }^{4} \mathrm{~J}$ Bréaud, ${ }^{4} \mathrm{~J}$ Valla, ${ }^{3} \mathrm{GM}$ Lacombe, ${ }^{5} \mathrm{M}$ Orsini, $5 \mathrm{JP}$ Daures, ${ }^{1} \mathrm{~F}$ Paris, ${ }^{2} \mathrm{~K}$ McElreavey, ${ }^{1} \mathrm{C}$ Sultan. ${ }^{\prime} \mathrm{CHU}$ Montpellier, Montpellier; ${ }^{2}$ Institut Pasteur, Paris; ${ }^{3} \mathrm{APHM}$, Marseille; ${ }^{4} \mathrm{CHU}$ Nice, Nice; ${ }^{5}$ Université Montpellier 1, Montpellier, France

Background and Aims Alterations in the androgen sensitivity pathway have been identified in severely undermasculinized boys, and mutations of the androgen-receptor gene (AR) are usually 